\title{
Black grouse in Czech Republic and its parasites
}

\author{
I. JANKOVSKA ${ }^{1}$, V. BEJCEK ${ }^{2}$, I. LANGROVA ${ }^{1}$, P. VÁLEK ${ }^{1}$, J. VADLEJCH ${ }^{1}$, Z. ČADKOVÁ ${ }^{1}$ \\ ${ }^{1}$ Department of Zoology and Fisheries, Faculty of Agrobiology, Food and Natural resources, Czech University of Life \\ Science Prague, Kamycka 129, 16521 Praha 6 Suchdol, Czech Republic, E-mail: jankovska@af.czu.cz; \\ ${ }^{2}$ Department of Ecology, Faculty of Environmental Sciences, Czech University of Life Science Prague, Kamycka 957, \\ 16521 Praha 6 Suchdol, Czech Republic
}

\begin{abstract}
Summary
According to the newest data (2010), the state of the black grouse is in decline in the Czech Republic. One of the reasons for this decline is the parasitic infection. The examination of 170 faecal specimens disclosed 6 species of parasites. Helminth eggs were found in $50 \%$ of the examined faecal specimens. The following eggs were found: cestode Hymenolepis spp. (28\%), with the highest prevalence $(84 \%)$ and mean intensity (1076 EPG) in spring; nematodes Trichostrongylus tenuis (24\%), and Ascaridia compar (3\%) with a mean intensity of 11 and 12 EPG, respectively. Coccidia infections were present in $1 \%$ of faecal specimens only in spring, with an intensity of 35 OPG. However, in the following year, Eimeria lyruri was the most abundant parasite in the faecal specimens. During the second year of our research, the prevalence of $E$. lyruri was $28 \%$; the highest prevalence $(67 \%)$ was in summer with an intensity of up to 9433 OPG.
\end{abstract}

Keywords: Tetrao tetrix; faecal specimen; parasite; Czech Republic

\section{Introduction}

Sublethal parasite infections may cause mortality indirectly by exposing the host to predation. Intestinal helminth parasites are common in forest grouse and these grouse are valuable prey for several species of predators. There is a hypothesis that parasite infection makes the host more vulnerable to predation. Disease and parasites have been also proposed as factors associated to the decline in numbers of several Tetraonidae species (Obeso et al., 2000). In Czech Republic is a decreasing trend of the black grouse numbers at present, the numbers of black grouse still decreases, in the years $2008-2010$ were found about 600 male black grouse (Table 1), in 2000 - 2003 numbers were estimated at 800 to 1000 cocks.

Of these, more than one third occurs in the Krusne hory
Mts. (Š́t'astný et al., 2006). In the Czech Republic, the last exceptional shooting permits were issued in 1995. The present declining trend in the numbers of black grouse in the Czech Republic does not suggest that their shooting could be renewed. Since black grouse is the protected species and shooting is not licensed, the presence of helminths was realized first of all by the coproovoscopical method. The parasitic helminths of black grouse (Tetrao tetrix) were hitherto subject of few studies (Baruš \& Groschaft, 1965; Zajíček \& Páv, 1972; Rosický et al., 1974; Baruš et al., 1984) in the Czech Republic. To fill up the gap, we examined black grouse faeces for eggs or oocysts of parasites in $2002-2003$. The aim of the present study was to collect basic data about parasitoses in survival free living black grouses of Krusne hory Mts. This paper describes changes in faecal egg counts of black grouse from Krusne hory Mts. area in 2002 and 2003. The objective of this work was to determine the composition of the parasite comunity of natural population of this species in the Krusne hory Mts. (CR).

\section{Material and methods}

Monitored area is located in the upper parts of the Krusne hory Mts. (NW Bohemia) mountains where black grouse (Tetrao tetrix) appear frequently. In the past, a large part of the Krusne hory Mts. was affected by industrial polutants. After the forest ecosystems had disintegrated, suitable conditions for the presence of black grouse (Tetrao tetrix) developed.

Black grouse faeces were collected from monitored area (Krusne hory Mts., NW Bohemia). In total of 170 faecal specimens, two digestive tracts and feathers from black grouse (Tetrao tetrix) collected during 2002 (90 faecal specimens) and 2003 (80) faecal specimens) were examined parasitologically.

We quantified the excretion of parasite forms as EPG (eggs per gram of faeces) or OPG (oocysts per gram of faeces) 
Table 1. Black grouse numbers in selected „Special Protection Areas" of Czech Republic (black grouse is there the subject of the protection) and total estimated count in all Czech Republi in the year 2010

\begin{tabular}{ccc}
\hline bird locality & year & $\begin{array}{c}\text { male grouse } \\
\text { number }\end{array}$ \\
\hline $\begin{array}{c}\text { Novodomské rašeliniště - Kovářská } \\
\text { Východní Krušné hory }\end{array}$ & 2010 & 63 \\
Jizerské hory & 2010 & 81 \\
Krkonoše & 2008 & $104-107$ \\
Šumava & 2008 & 112 \\
\hline total estimated count & 2010 & $50-60$ \\
in all Czech Republic & $\mathbf{2 0 1 0}$ & $\mathbf{6 0 0}$ \\
\hline
\end{tabular}

by flotation and count in a MacMaster chamber (Whitlock, 1948). Samples were taken every month.

The digestive tract was separated into the stomach, small and large intestine. The contents and washings were collected separately from each part and examined microscopically. Mites were collected from black grouse feathers found in monitored area. The feathers were put in decanter with $70 \%$ ethanol for 1 hour and mites fell to bottom of decanter. After decantation, the suspension from bottom was examined microscopically and mites were calculated.

The dependence between the occurrence of helminths eggs in black grouse faeces in monitored area and the season of the year was analysed by using SAS (SAS Institute, 2002). The level of significance was set at $\mathrm{P}<0.01$.

\section{Results}

In the monitored area, the black grouses (Tetrao tetrix) were parazited by coccidia Eimeria lyruri, cestode Hymenolepis spp., 3 nematodes Trichostrongylus tenuis, Aonchotheca caudinflata (syn. Capillaria caudinflata), Ascaridia compar and at the least by feather mites Pterolichus obtusus (Table 1).

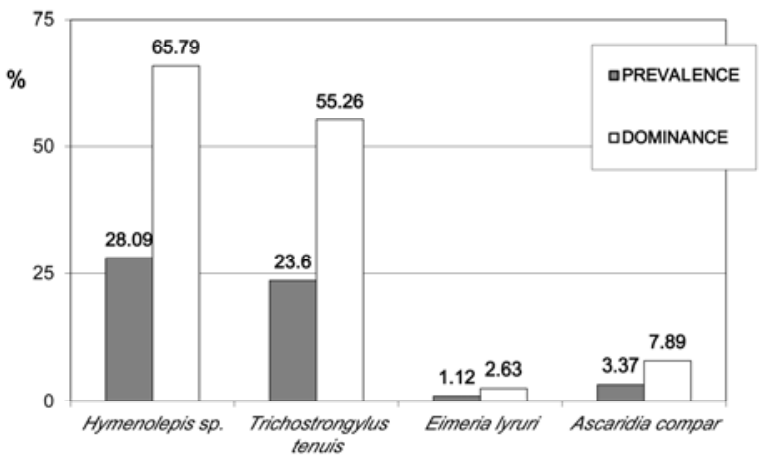

Fig. 1. Prevalence and dominance of black grouse (Tetrao tetrix) parasites in 2002

Nematode Trichostrongylus tenuis and Hymenolepis spp. eggs were found on an annuals basis in the year 2002 and 2003, respectively (Figs. 1 and 2). Infrequently found species were Eimeria lyruri, Ascaridia compar and Aonchotheca caudinflata. The most dominant parasites were Hymenolepis spp. in 2002 and Eimeria in 2003 (Figs. 1 and 2).

Feather mites Pterolichus obtusus (Astigmata: Pterolichidae) were found in feathers of 2 dead black grouse from monitored area of Krusne hory Mts. in both years.

In 2002, parasite eggs or oocystes were found in $50 \%$ of the examined faecal specimens. $29 \%$ black grouses were invaded by one species of parasites, by two species $14 \%$ and $0 \%$ black grouse were invaded by three or more species of parasites. Free of parasites were $57 \%$ black grouse.

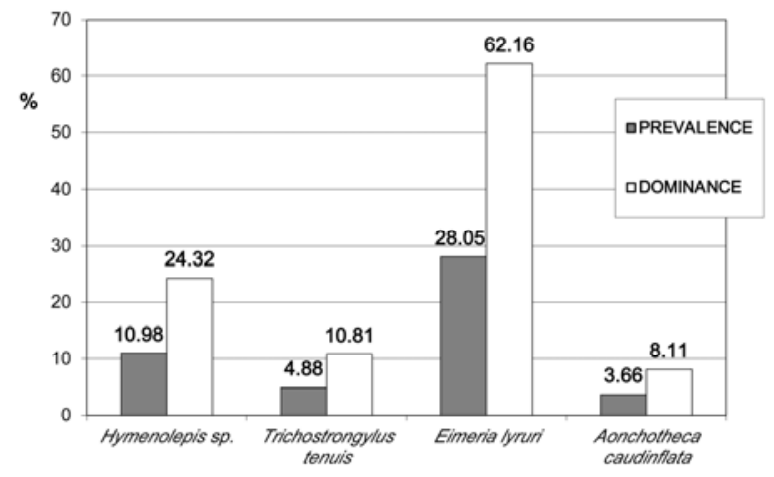

Fig. 2. Prevalence and dominance of black grouse (Tetrao tetrix) parasites in 2003

Cestoda infections (Hymenolepis spp.) in 2002 were present in $28 \%$ of faecal specimens, with high prevalence $(84 \%)$ and mean intensity (1076 eggs per gram of faeces) in spring (Fig. 3). Nematoda infections (Trichostrongylus tenuis and Ascaridia compar) were present in $24 \%$ of faecal specimens with mean intensity of 11 eggs or pre-infective larvae in $1 \mathrm{~g}$ of faeces, and $3 \%$ with mean intensity 12, respectivelly. Coccidia infections (Eimeria lyruri) were present only in spring of 2002 in $1 \%$ of faecal specimens, with the intensity of 35 oocysts in $1 \mathrm{~g}$ of faeces (Fig. 3).

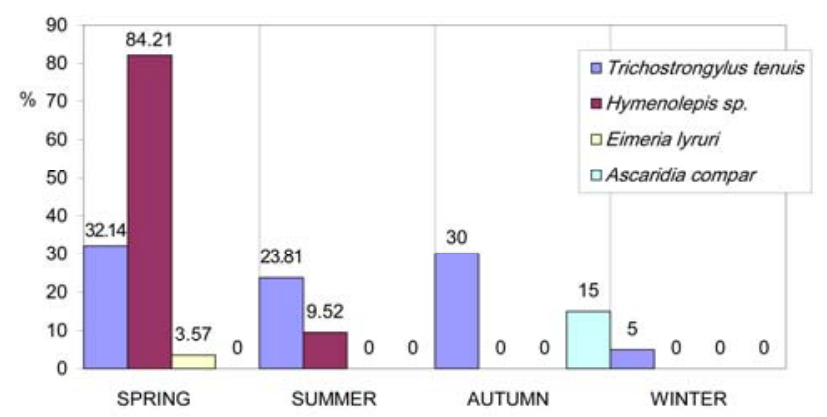

Fig. 3. Prevalence of parasites eggs/oocysts in black grouse faeces in seasons 2002

FEC showed one peak (Table 1) in spring (April 2002) with cestode Hymenolepis spp. (P > 0.01). In summer 2002, nematodes (Trichostrongylus tenuis) were dominant, in autumn 2002 were dominant nematodes (Trichostrongylus tenuis and Ascaridia compar) but in low intensity. In winter of 2002 Trichostrongylus tenuis eggs were found only.

In 2003, parasite eggs or oocystes were found in $46 \%$ of the examined faecal specimens. The most dominant parasite was coccidia (Eimeria lyruri), especially in May-July (Fig. 4). Prevalence E. lyruri in the 2003 was $28 \%$, the mean intensity of infection by E. lyruri was 1087 oocysts in $1 \mathrm{~g}$ of faeces $(20-9430 \mathrm{OPG})$.

Cestoda infections (Hymenolepis spp.) in 2003 were repre- 


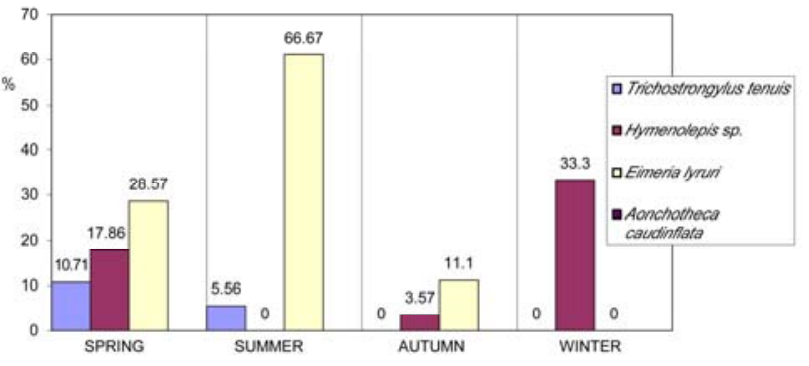

Fig. 4. Prevalence of parasites eggs/oocysts in black grouse faeces in seasons 2003

sented in $11 \%$ of faecal specimens, with intensity (4 25795 eggs per gram of faeces).

Nematode infections (Aonchotheca caudinflata and Trichostrongylus tenuis) were present only in March/April 2003, in $5 \%$ for nematode Trichostrongylus tenuis and 4\% for nematode Aonchotheca caudinflata with mean intensity 7 EPG (eggs in $1 \mathrm{~g}$ of faeces) and 5 EPG, respectivelly.

Also feather mites Pterolichus obtusus (Astigmata: Pterolichidae) were found in the black grouse feathers living in the monitored area in the year 2002 and 2003, it was 40 mites in $20 \mathrm{~g}$ of feathers ( 2 mites in $1 \mathrm{~g}$ ) and 13 mites in $1 \mathrm{~g}$ of feathers, respectively.

\section{Disscusion}

Parasites were mentioned as one of the factors involved in the regulation of galliform populations (Hudson et al., 1992ab). Isomursu et al. (2008) evaluated this hypothesis by comparing the intestinal parasite infection status of arouse hunted with a trained dog to that of grouse hunted without a dog and they foud out cestode infection were more common in grouse hunted with a dog supporting the hypothesis. Authors also describe cestodes were mostly parasites of juvenile grouse but even among juveniles only, cestodes were more prevalent in dog-assisted hunting bag.

Also in this study was the most dominant parasite Hymenolepis spp. Cestoda infections (Hymenolepis spp.) were present in $28 \%$ of faecal specimens, with high prevalence $(84 \%)$ and mean intensity (1076 eggs per gram of faeces) in spring (Fig. 3). Isomursu et al. (2008) suggest that mammalian predators could prey more selectively on parasitized individuals and that intestinal parasites may contribute to the high mortality of juvenile grouse throught increased predation.

Several studies have shown that a significant fraction of the grouse present within an area in autumn will die during the winter. There is negative relationship between parasite intensities and grouse body condition. The most infected birds will have a nutritional disadvantage at the start of the winter season (Schei et al., 2001).

Coproovoscopical investigation monitored black grouse population showed a low infestation with parasites during winter. There was very hight prevalence and intensity of helminth eggs in black grouse faeces in spring. It can be related to diet, beetles are accessible as intermediate host of tapeworms in spring. Also Höglund et al. (1992) published that April to June is the time of the year when parasites are most abundant.
Mainly green shoots of plants, seeds, berries, buds of shrubs and trees, acorns constitute the food of black grouse. In our area, it was mainly cotton grass (Eriophorum vaginatum) grass (Avenella flexuosa) and Vaccinium sp., blueberries (Vaccinium uliginosum, Vaccinium myrtillus, Vaccinium vitis-idea, Vaccinium oxycoccos), moss (Sphagnum sp.), heather Calluna vulgaris), dwarf pine Pinus mugo and birch Betula sp. (Málková et al., 2000), only young birds take particularly insects as food. The black grouse (Tetrao tetrix) is frequently parazited by a cestoda of the genus Hymenolepis, which is not very infective though (Belleau \& Léonard, 1991). Eggs of this tapeworm (Hymenolepis spp.) were found in our study mainly in spring with very high intensity of infection. FEC showed one peak in spring (April 2002) with cestode Hymenolepis sp., probably due diet composition (ingestion of intermediate host) and sexual activity (maturation of proglottides). Bezubik (1960) from Poland describes exclusively tapeworms Raillietina urogalli and $R$. cesticillus. Intermediate hosts of those tapeworms are insects of the order Coleoptera, they are eaten mainly by young birds. We found no those cestodes which are charakteristic parasites of genus Tetrao (Raillietina sp. and Davainea sp.) similarly as Obtuso et al. (2000), which were studied the Cantabrian Carpercaillie (Tetrao urogalus).

The composition of helminthofauna depends on the kind of food taken. The absence of trematoda and acanthocephala in the examined material is due to the fact that their intermediate hosts are not eaten by the black grouse (Bezubik, 1960). There occur, however, parasites of a simple development (Trichostrongylus tenuis, Ascaridia compar, Aonchoteca caudinflata), or such of which the intermediate hosts are insects that constitute at least in some periods of life additional food to black grouse (Hymenolepis sp.). In Finnish black grouse (Raitis \& Helminen, 1969) Ascaridia compar (45\% prevalence) was the most common intestinal parasite. Nematodes of Ascaridia compar and Aonchoteca caudinflata found in black grouses also Frosio et al. (2000) in Orobie Alps (Italy). Those nematodes (Ascaridia compar and Aonchoteca /Capillaria/ caudinflata) were found also by Bezubik (1960) in Poland. Population studies on red grouse (Lagopus lagopus scoticus) show a negative correlation between breeding succes and the intensity of infection by Trichostrongylus (Hudson et al., 1998).

Coccidia infections (Eimeria lyruri) were present only in spring of 2002 in $1 \%$ of faecal specimens; with the intensity of 35 oocysts in $1 \mathrm{~g}$ of faeces. However, Eimeria lyruri was the most abundant parasite in faecal specimens in 2003. The prevalence in 2003 was $28 \%$ with high intensity up to 9433 oocysts in $1 \mathrm{~g}$ of faeces. Although the reasons for the increase are not clear, possible factors that could affect the prevalence include higher host density and changes in the physical characteristics of the black grouse's habitat that enhance oocyst survival in the external environment. Fehlberg and Pohlmeyer (1991) found coccidia infection in $23 \%$ of black grouses which perished in the aviaries in Hannover (Germany). Diseases and parasites are by one of factors associated to the decline in numbers of several Tetraonidae species. Number of lekking black grouse in monitoring area 
(in the year 2010) is still declined. It can be caused also Eimeria infection. A coprological study found out high intensity of Eimeria lyruri infection (9433 OPG) in this area. Parasites coud have some influence on the predation of back grouse by foxes. Predators are removing a large proportion of the parasite population and have relatively small influence on the host population so the host population escapes the regulatory role of the parasite (Hudson et al., 1992a).

Also ectoparasites play important roles in the lives of birds. Feather mites are highly specialised plumage and skin ectoparasites that are variously adapted for inhabiting certain microhabitats on a bird's body (Dabert \& Mironov, 1999) Feather mites Pterolichus obtusus (Astigmata: Pterolichidae) were found in the 2 dead black grouse feathers from monitored area in 2003. There were 40 mites in $20 \mathrm{~g}$ of feathers ( 2 mites in $1 \mathrm{~g}$ ) and 13 mites in $1 \mathrm{~g}$ of feathers, respectively. Those mites live in the plumage and seldom cause trouble unless present in massive numbers.

The results of the parasitological study confirm that in freeliving black grouse parasitofauna is characterised by a low number of parasite species. In one faecal specimen, there were eggs of $0-2$ parasite species only. The results also show that black grouses from immission affected area are most frequently invaded by parasite that has good conditions for its development and dissemination in this area. Seasonal diet composition has a considerable effect because faecal samples were most infected in spring $(\mathrm{P}>0.01)$.

An estimation of oocysts and worm eggs is still avaluable information about the body condition of the birds, and should be included in future black grouse monitoring.

\section{Acknowledgement}

The research was supported by S grant of MSMT CR.

\section{References}

BARUŠ, V., GROSchaft, J. (1965): The occurence of the nematodes Syngamus trachea (Montagu, 1811) and $S$. (Ornithogamus) merulae (Baylis, 1926) in free-living birds of Czechoslovakia. Věš. Čs. Spol. Zool., 29: 97 - 107

BARUŠ, V., SONIN, M. D., TENORA, F., Wiger, R. (1984): Survey of nematodes parasitising the genus Tetrao (Galliformes) in the Palearctic region. Helminthologia, 21:3-15 BELlEAU, E., LÉONARD, P. (1991): Internal parasites of the rock partridge (Alectoris graeca saxatilis), ptarmigan (Lagopus mutus) and black grouse (Tetrao tetrix) in the French High Alps. Gibier Faune Sauvage, 8: 161 - 173

BEZUBIK, B. (1960): Helminth parasites of black grouse (Lyrurus tetrix) and capercaillie (Tetrao urogallus). Acta Parasitol. Polon., 3: 37 - 46

Cattadori, I. M., Merler, S., Hudson, P. J. (2000): Searching for mechanisms of synchrony in spatially structured gamebird populations. J. Anim. Ecol., 69: 620-638 DABERT, J., MiRONOV, S. V. (1999): Origin and evolution of feather mites (Astigmata). Exp. Appl. Acarol., 23: 437 - 454

RECEIVED APRIL 14, 2011
Dobson, A. P., Hudson, P. J. (1992): Regulation and stability of a free-living host-parasite system Trichostrongylus tenuis in Red Grouse. II Population models. J. Anim. Ecol. 61: $487-500$

Von FehlberG, U., PoHLMeyer, K. (1991): Erkrankung des Birkhuhnes (Tetrao tetrix) in Volierenhaltung. Wien. Tierärztl. Mschr., 78: $387-390$

Frosio, G. D., Sala, M., Lanfranchi, P., Gallazi, D. (2000): Intestinal helminths in free living galliformes in Orobie Alps and management implications. La Selezione Veterinaria $8-9 / 2000,38^{\circ}$ Convegno SIPA: $817-825$

Höglund, J., Alatalo, R. V., LundBerg, A. (1992): The effects of parasites on male ornaments and female choice in the lek-breeding black grouse (Tetrao tetrix). Behav. Ecol. Sociobiol., 30: $71-76$

Hudson, P. J., Dobson, A. P., Newborn, D. (1992a): Do parasites make prey vulnerable to predation? Red grouse and parasites. J. Anim. Ecol., 61: 681 - 692

Hudson, P. J., NewBorn, D., Dobson, A. P. (1992b): Regulation and stabilityof a free-living host-parasite system: Trichostrongylus tenuis in red grouse. I. Monitoring and parasite reduction experiments. J. Anim. Ecol., 61: 477 - 486 Hudson, P. J., Dobson, A. P., Newborn, D. (1998): Prevention of population cycles by parasite removal. Science, 282: 2256 - 2258. DOI: 10.1126/science.282.5397.2256

Isomursu, M., Ratti, O., Helle, P., Hollmen, T. (2008): Parasitized grouse are more vulnerable to predation as revealed by a dog-assisted hunting study. Ann. Zool. Fennici, 45(6): $496-502$

MÁlkovÁ, P., BejČEK, V., ŠŤAstnÝ, K., ŠímovÁ, P., THomsovÁ, H. (2000): Ecology of the Black Grouse (Tetrao tetrix) on the Grünwald Peat Bog in the Krusne hory Mts. Cahiers d'Ethologie, 20(2 - 3 - 4): $421-438$

OBESO, J. R. (2000): Intestinal parasites in the Cantabrian Carpercaillie Tetrao urogalus cantabricus: a coprological study. Ardeola, 47: 191 - 195.

RAITIS, T., Helminen, M. (1969): Ascaridia compar the most frequent intestinal parasite of gallinaceous birds in Finland. Suom. Riista, 21:27 - 39

RosickÝ, B., BARUŠ, V., BEJŠOVEC, J. (1974): Natural focality of poultry nematodoses in Czechoslovakia. Acta Sc. Nat. Brno, 8, 4: $1-43$.

Schei, E., Holmstad, P., Skorping, A. (2001): Can parasite-induced winter mortality in grouse (Lagopus lagopus L.) be detected by a decrease in aggregation patterns? Scandinavian society for parasitology, XX symposium, Stockholm, from: www.mtc.ki.se/groups/wahlgren/Abs.htm ŠŤASTNÝ, K., BEJČEK, V., HudeC K. (2006): Atlas of breeding birds in the Czech Republic in 2001 - 2003. Aventinum, Praha: 463pp.

Whitlock, J. A. (1948): Some modifications of the McMaster helminth egg-counting technique and apparatus. J. Counc. Sci. Ind. Res. Aust., 21: $177-180$.

ZAJÍČEK, D., PÁV, J. (1972): Parasitofauna of Tetraonidae and Otididae Birds in Czech. Final Report of FGMRI: 1105 (In Czech)

ACCEPTED JANUARY 30, 2012 